www.volsu.ru

DOI: https://doi.org/10.15688/nsr.jvolsu.2021.2.3

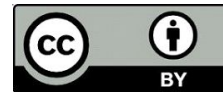

UDC 616.31:57.089(470.45)

LBC 56.68(2P-4Вог)

\title{
ENVIRONMENTAL ASPECTS OF DENTAL IMPLANTATION IN A LARGE INDUSTRIAL CENTER (ON THE EXAMPLE OF VOLGOGRAD)
}

\author{
Tatyana S. Lyzo \\ Volgograd State University, Volgograd, Russian Federation \\ Anastasia A. Korchagina \\ Volgograd State University, Volgograd, Russian Federation \\ Anna S. Krylova \\ Volgograd State University, Volgograd, Russian Federation
}

\begin{abstract}
Annotation. Dental implantation is a method widely used in dental practice, based on the process of osseointegration - the formation of a strong connection between the inserted implant and the bone tissue. The use of these implants has a number of problems with the osseointegration process associated primarily with the development of pathogenic microflora and possible damage. To combat these difficulties, various materials are being developed for coating implants with the addition of bioactive elements, which reduce the possibility of infection by pathogenic microorganisms, as well as increase strength, improve osseointegration and biocompatibility of implants with bone tissue. The most effective coatings at the moment are hydroxyapatite and calcium triphosphate, using such bioactive elements as growth factors and components of the bone matrix, as well as chitosan, silver and gold salts. When using dental implants, monitoring of osseointegration is necessary to minimize bone loss, and fluoroscopy is the most suitable method for this. The state of the environment has a strong impact on the health of citizens. Volgograd has a high level of environmental pollution, which directly affects the frequency of diseases, including diseases of the oral cavity and teeth. According to the statistics of people visiting dental hospitals, the values in the Krasnoarmeyskiy region exceed, while the number of implants installed per year in this region is low and amounts to 1500 , while in the Voroshilovskiy region, with the number of patients being half as much, the number of implants is more than 1000 all associated with the increased use of surgical services for the extraction of teeth in the area.
\end{abstract}

Key words: dental implantation, osseointegration, ecology, environmental pollution, health level.

Citation. Lyzo T.S., Korchagina A.A., Krylova A.S. Environmental Aspects of Dental Implantation in a Large Industrial Center (On the Example of Volgograd). Prirodnye sistemy i resursy [Natural Systems and Resources],

ЭКОЛОГИЧЕСКИЕ АСПЕКТЫ ДЕНТАЛЬНОЙ ИМПЛАНТАЦИИ В КРУПНОМ ПРОМЫШЛЕННОМ ЦЕНТРЕ (НА ПРИМЕРЕ Г. ВОЛГОГРАДА)

\author{
Татьяна Сергеевна Лызо
}

Волгоградский государственный университет, г. Волгоград, Российская Федерация

Анастасия Александровна Корчагина

Волгоградский государственный университет, г. Волгоград, Российская Федерация

Анна Сергеевна Крылова

Волгоградский государственный университет, г. Волгоград, Российская Федерация 
Аннотация. Дентальная имплантация - метод, повсеместно применяемый в стоматологической практике, основанный на процессе остеоинтеграции - образовании прочной связи вставленного имплантата с костной тканью. Применение данных имплантатов обладает рядом проблем с процессом остеоинтеграции, связанных прежде всего с развитием патогенной микрофлоры и возможными повреждениями. Для борьбы с данными сложностями разрабатываются различные материалы для покрытия имплантатов с добавлением биоактивных элементов, которые снижают возможность заражения патогенными микроорганизмами, а также увеличивают прочность, улучшают остеоинтеграцию и биосовместимость имплантатов с костной тканью. Наиболее эффективными покрытиями на данный момент являются гидроксиапатит и кальция трифосфат, с использованием таких биоактивных элементов, как факторы роста и компоненты костного матрикса, а также хитозан, соли серебра и золота. При использовании дентальных имплантатов необходим мониторинг остеоинтеграции для минимизации потери костной ткани, и наиболее подходящим для этого методом является рентгеноскопия. Состояние окружающей среды имеет сильное влияние на здоровье граждан. В Волгограде высокий уровень загрязнения окружающей среды, что напрямую влияет на частоту заболеваний, в том числе заболеваний полости рта и зубов. По статистике в Красноармейском районе преобладающее число обращений людей в стоматологические клиники, при этом количество установленных имплантатов в год в данном районе невысок и составляет 1500 , в то же время в Ворошиловском районе при количестве пациентов в два раза меньшем, количество имплантатов более 1000 , что скорее всего связано с повышенной активностью применения хирургических услуг по удалению зубов в данном районе.

Ключевые слова: дентальная имплантация, остеоинтеграция, экология, загрязнения окружающей среды, уровень здоровья.

Цитирование. Лызо Т. С., Корчагина А. А., Крылова А. С. Экологические аспекты дентальной имплантации в крупном промышленном центре (на примере г. Волгограда) // Природные системы и ресурсы. 2021. - T. 11, № 2. - С. 19-26. - DOI: https://doi.org/10.15688/nsr.jvolsu.2021.2.3

\section{Эколого-биологические аспекты остеоинтеграции \\ и дентальной имплантации}

В дентальной имплантации в качестве базовой применяется технология внутрикостной имплантации с целью создания несъемной ортопедической конструкции на основе процесса остеоинтеграции, т.е. образовании связи между имплантатом и костной тканью. Данный метод является активно развивающимся и повсеместно применяемым в стоматологической практике [7].

Основными причинами осложнения при использовании имплантатов являются проблемы остеоинтеграции, в основном из-за наличия патогенной микрофлоры и микротравм [10; 17]. С целью решениях данных проблем проводятся разработки новых материалов, которые бы позволили достичь стабильной связи имплантат-кость, и основным направлением является модификация покрытия имплантата $[4 ; 7 ; 15]$.

Наиболее активно используемыми покрытиями с высокой биосовместимостью являются гидроксиапатит и кальция трифосфат $[4 ; 11]$.
Использование биоактивных элементов, таких как факторы роста и компоненты костного матрикса [12], а также хитозан [3], соли серебра и золота [13], позволяет избежать заражения патогенными микроорганизмами, улучшает остеоинтеграцию и повышает устойчивость имплантата к разрушению [4; 8].

Перспективными, но на данный момент достаточно сложными и дорогостоящими методами является использование наноструктурных поверхностей [8], нанотрубок [6], наночастиц [2] и нанопленок [16], которые благоприятно влияют на пролиферацию и дифференцировку остеоцитов [5; 14].

У пациентов необходимо проводить мониторинг остеоинтеграции и в период приживления имплантата и при дальнейшей его эксплуатации для минимизации потери костной ткани вокруг имплантата [9]. И наиболее эффективным методом мониторинга является рентгенологический [1].

В условиях крупных промышленных городов, включая г. Волгоград, процент заболеваемости населения, в том числе и стоматологических, имеет сильную зависимость от уровня экологической обстановки. Поэтому необходимо провести анализ экологической си- 
туации в Волгограде по таким критериям, как превышение выбросов по конкретным вещества, количество отходов и их влияние на показатели заболеваемости, определение групп болезней с наибольшими показателями заболеваемости, уровень заболевания среди детского, подросткового и взрослого населения.
Данные из таблицы подтверждают, что уровень загрязнения окружающей среды напрямую влияет на процент заболеваемости населения. Таким образом, остро стоит необходимость поддерживать экологическую обстановку на должном уровне для обеспечения здоровой жизни граждан.

\section{Характеристика состояния окружающей среды в г. Волгограде, уровень загрязнения и его влияние на показатели заболеваемости}

\begin{tabular}{|c|c|c|}
\hline Год & Превышения по веществам & Показатель заболеваемости \\
\hline 2010 & $\begin{array}{l}\text { Фенол, формальдегид, хлористый } \\
\text { водород, окислы азота, хлористый и } \\
\text { фтористый } \quad \text { водород. Количество } \\
\text { отходов составляет } 872,1 \text { тыс. тонн }\end{array}$ & $\begin{array}{l}\text { Болезни эндокринной системы, крови, врожденным поро- } \\
\text { кам развития, болезням кожного покрова, новообразова- } \\
\text { ниям, заболеваниям костной системы }\end{array}$ \\
\hline 2011 & $\begin{array}{l}\text { Возросло количество выбросов хи- } \\
\text { мической, металлургической неф- } \\
\text { теперерабатывающей промышлен- } \\
\text { ности. Количество отходов соста- } \\
\text { вило } 2133,8 \text { тыс. тонн, что на } \\
144,7 \text { б больше в сравнении с } \\
2010 \text { годом }\end{array}$ & $\begin{array}{l}\text { Болезни эндокринной системы, болезни крови и крове- } \\
\text { творных органов, нарушения обмена веществ, появилась } \\
\text { проблема ожирения. Уровень заболеваемости детей силь- } \\
\text { но возрос }\end{array}$ \\
\hline 2012 & $\begin{array}{l}\text { Уровень загрязнения атмосферного } \\
\text { воздуха диоксидом серы, фторидом } \\
\text { водорода и бенз(а)пиреном, окси- } \\
\text { дом азота, оксидом углерода и ам- } \\
\text { миаком вырос. Количество отходов } \\
\text { в сравнении с } 2011 \text { годом увеличи- } \\
\text { лось на } 663,4 \text { тыс. тонн }\end{array}$ & $\begin{array}{l}\text { Среди взрослого населения увеличилось число заболева- } \\
\text { ний костной системы и новообразований. Так же увели- } \\
\text { чилось значение заболеваемости среди детей и подрост- } \\
\text { ков по таким классам болезней как: заболевания пищева- } \\
\text { рительной и эндокринной систем, врожденные пороки } \\
\text { развития. Уровень заболеваемости составил 46071,6 на } \\
100 \text { тыс. взрослого населения }\end{array}$ \\
\hline 2013 & $\begin{array}{l}\text { Высокие концентрации пыли, окси- } \\
\text { да азота, оксида углерода фенола, } \\
\text { формальдегида, оксида углерода, } \\
\text { диоксида азота }\end{array}$ & $\begin{array}{l}\text { Возрос уровень заболеваемости детей по заболеваниям } \\
\text { эндокринной системы, нарушениям обмена веществ, но- } \\
\text { вообразованиям, врожденным порокам развития и хромо- } \\
\text { сомным аномалиям, системы кровообращения. Уровень } \\
\text { заболеваемости составил 50003,6 на } 100 \text { тыс. взрослого } \\
\text { населения }\end{array}$ \\
\hline 2014 & $\begin{array}{l}\text { Было зафиксировано большое ко- } \\
\text { личество аварийных ситуаций. } \\
\text { Среди загрязняющих веществ были } \\
\text { выявлены углеводороды, толуол, } \\
\text { ксилол, бензол, этилбензол, хлори- } \\
\text { стый водород, аммиак, хлор, фенол, } \\
\text { сероводород, } \\
\text { пестициды. }\end{array}$ & $\begin{array}{l}\text { Рост заболеваемости по болезням системы кровообраще- } \\
\text { ния, эндокринной системы, новообразованиям, ожирени- } \\
\text { ем. Уровень заболеваемости среди взрослого населения } \\
\text { составил } 81854,3 \text { на } 100 \text { тыс. нас., а среди детского - } \\
233266,0 \text { на } 100 \text { тысяч }\end{array}$ \\
\hline 2015 & $\begin{array}{l}\text { Превышение } \quad \text { концентраций } \\
\text { фосфат-ионам }\end{array}$ & $\begin{array}{l}\text { Увеличение числа развития онкологических заболеваний } \\
\text { среди населения }\end{array}$ \\
\hline 2016 & $\begin{array}{l}\text { Зафиксировано высокое содержа- } \\
\text { ние хлоридов, сульфатов и органи- } \\
\text { ческих соединений в водоемах. } \\
\text { Увеличение диоксида азота, пыли и } \\
\text { формальдегида в атмосферном воз- } \\
\text { духе }\end{array}$ & $\begin{array}{l}\text { Увеличились показатели по заболеваниям эндокринной и } \\
\text { нервной систем, органов дыхания, кожи и подкожной } \\
\text { клетчатки. Превышение заболеваемости у взрослых по } \\
\text { болезням эндокринной системы, у детей - по болезням } \\
\text { крови и кроветворных органов. Увеличение заболеваемо- } \\
\text { сти среди подросткового населения на } 12,9 \text { \% в сравнении } \\
\text { с } 2015 \text { годом }\end{array}$ \\
\hline 2017 & $\begin{array}{l}\text { Превышение концентрации фенола, } \\
\text { формальдегида, сероводорода, ок- } \\
\text { сида углерода, хлорида водорода, } \\
\text { пыли, диоксида азота, этилбензола, } \\
\text { м-ксилола, о-ксилола }\end{array}$ & $\begin{array}{l}\text { Рост заболеваемости по болезням: расстройства питания, } \\
\text { болезни эндокринной системы, нарушения обмена ве- } \\
\text { ществ, болезни системы кровообращения, болезни уха, } \\
\text { болезни органов дыхания. } \\
\text { Показатель заболеваемости у детей увеличился на } 4,1 \text { \%, } \\
\text { у подростков - на } 6,6 \text { \% и у взрослых - на } 1,6 \text { \% }\end{array}$ \\
\hline
\end{tabular}


Окончание таблицьь

\begin{tabular}{|c|c|c|}
\hline Год & Превышения по веществам & Показатель заболеваемости \\
\hline 2018 & $\begin{array}{l}\text { Большое число несанкционирован- } \\
\text { ных свалок. Было обнаружено вы- } \\
\text { сокое содержание азота аммоний- } \\
\text { ного в стоках }\end{array}$ & $\begin{array}{l}\text { Превышение уровня заболеваемости по болезням костно- } \\
\text { мышечной системы, болезням эндокринной системы, не- } \\
\text { которым инфекционным и паразитарным болезням, бо- } \\
\text { лезням крови, болезням уха и сосцевидного отростка, бо- } \\
\text { лезням нервной системы, болезням глаза и его придаточ- } \\
\text { ного аппарата, врожденным аномалиям, травм, болезням } \\
\text { органов дыхания. Уровень заболеваемости детей вырос } \\
\text { на } 3,8 \text { \%, взрослых - на } 3,4 \text { \% }\end{array}$ \\
\hline 2019 & $\begin{array}{l}\text { В питьевой воде обнаружено высо- } \\
\text { кое содержание хлороформа, желе- } \\
\text { за, хлоридов, сульфатов, магния, } \\
\text { аммиака, фтора, марганца, натрия }\end{array}$ & $\begin{array}{l}\text { Увеличение числа заболеваний у детей по новообразова- } \\
\text { ниям, болезням эндокринной системы, кожи и подкожной } \\
\text { клетчатки, травмам и отравлениям, болезням нервной } \\
\text { системы, системы кровообращения, мочеполовой систе- } \\
\text { мы, врожденным аномалиям, болезням уха, некоторым } \\
\text { инфекционным и паразитарным болезням. Уровень забо- } \\
\text { леваемости у взрослого население вырос на } 0,9 \%\end{array}$ \\
\hline
\end{tabular}

\section{Материалы и методы исследования}

Клинические данные по обращению граждан на предмет «дентальной имплантации» были получены в государственных медицинских организациях стоматологического профиля в соответствии с лицензией, разрешающей оказание стоматологических услуг.

Отбор граждан производился по следующим критериям: наличие диагноза «Пародонтоз» и «Потеря зубов вследствие несчастного случая, удаления зубов или локализованного пародонтита, частичное отсутствие зубов».

Анализ состояния окружающей среды г. Волгограда. Из докладов о состоянии окружающей среды Волгоградской области за 2015-2018 гг. были взяты данные по загрязняющим веществам в атмосферном воздухе у крупнейших предприятий г. Волгограда и общие данные по загрязнению атмосферного воздуха в каждом районе. Оценивались такие показатели как: диоксид азота, формальдегид, оксид углерода, пыль, фенол, хлорид водорода, аммиак.

\section{Влияние экологических факторов на территориальную систему здравоохранения в области стоматологических услуг} в г. Волгограде

В Красноармейском районе, на территории которого расположено 2 крупных предприятия (АО «Каустик» и «ЛУКОЙЛ-Волгоград- нефтепереработка»), основными загрязняющими веществами являются: хлорид водорода, фенол и сероводород.

На территории Кировского района расположено ВОАО «Химпром», основными загрязняющими веществами являются: хлорид водорода, аммиак, пыль, фенол, сероводород и формальдегид.

На территории Советского района отсутствуют крупные тяжелые или химические промышленные предприятия, загрязняющие атмосферу, но при этом выявляются такие вещества как оксид углерода, пыль, фенол и диоксид азота.

В Ворошиловском и Центральном районах отсутствуют крупные тяжелые или химические промышленные предприятия, при этом они являются самыми незагрязненными районами.

ОАО «Завод базальтовой теплоизоляции - Волгоград» на территории Дзержинского района загрязняет атмосферу оксидом углерода, фенолом, сероводородом и диоксидом азота.

На территории Краснооктябрьского района работает одно из самых крупных тяжелых промышленных предприятий г. Волгограда - АО «ВМК «Красный Октябрь». При этом выявляются: хлорид водорода, оксид углерода, аммиак, пыль, фенол, диоксид серы, формальдегид и диоксид азота.

В Тракторозоводском районе имеется крупное тяжелое промышленное предприятие (АО «РУСАЛ Волгоград»), при этом выявля- 
ются такие вещества, как оксид углерода, пыль, фенол и диоксид азота (рис. 1). Несмотря на наличие заводов, в районе незначительное содержание загрязняющих атмосферу веществ.

В Красноармейском районе много людей с заболеваниями полости рта и зубов, при этом всего 1500 тысячи установленных имплантатов в год, в то время как в Ворошиловском районе почти в 2 раза меньше пациентов, а количество установленных имплантатов свыше 1000 (рис. 2). Это может быть связано с тем, что в Ворошиловском районе очень активно осуществляют хирургические услуги по удалению зубов.

\section{Выводы}

Выявлены зависимости между экологическими факторами и частотой услуг по дентальной имплантации в г. Волгограде.

Состояние окружающей среды в районах города Волгограда оказывает влияние на здоровье граждан, особенно на состояние зубов:

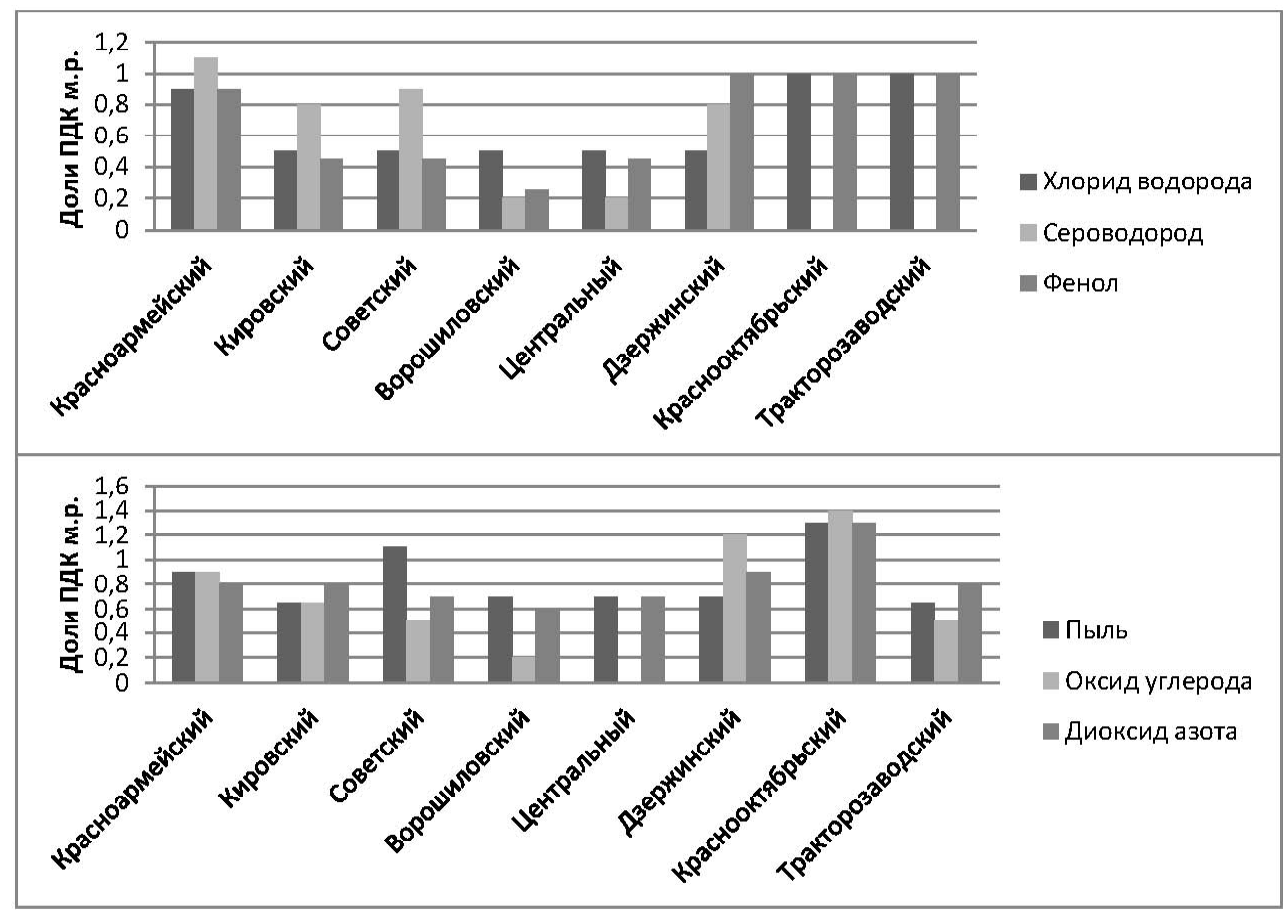

Рис. 1. Доли ПДК м.р. загрязняющих веществ с 2015 по 2018 гг. по районам г. Волгограда

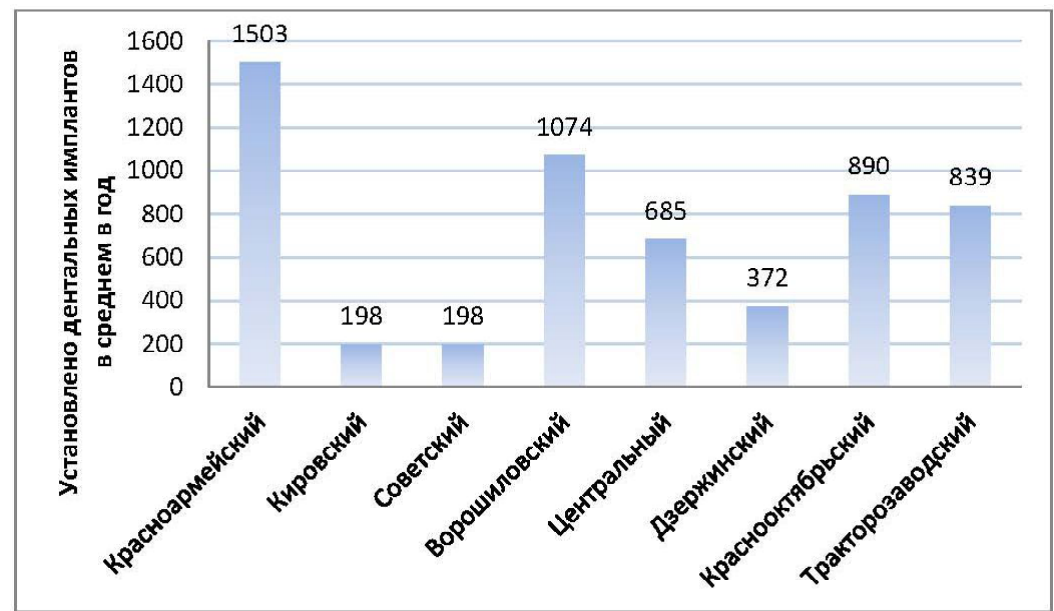

Рис. 2. Среднегодовое количество установленных дентальных имплантатов за 2015-2018 гг. в г. Волгограде 
в районах с тяжелых положением, где в атмосфере большое количество загрязняющих веществ, растет частота заболеваний полости рта, в частности зубов.

\section{СПИСОК ЛИТЕРАТУРЫ}

1. Костенко, Е. Я. Анализ методов оценки потери уровня костной ткани в периимплантатном участке на основе результатов рентгенологических исследований / Е. Я. Костенко, А. Т. Кенюк, 3. 3. Дычек // Современная стоматология. - 2016. - Т. 2, № 81. - С. 76-79.

2. Наноразмерные частицы - участники остеоинтеграции / В. В. Лабис [и др.] // Бюллетень Оренбургского научного центра УрО РАН. - 2016. № 1. - C. 1-18.

3. Остеоинтеграция имплантатов с биоактивной поверхностью, модифицированной напылением хитозана в эксперименте у крыс / В. В. Новочадов [и др.] // Российский медико-биологический вестник им. академика И.П. Павлова. - 2013. № 2. - C. 30-35.

4. Advances in Surfaces and Osseointegration in Implantology. Biomimetic Surfaces / M. Albertini [et al.] // Med. Oral Patol. Oral Cir. Bucal. - 2015. Vol. 20, № 3. - e316-e325. - DOI: https://doi.org/ 10.4317/medoral.20353.

5. Advancing Dental Implant Surface Technology - from Micron - to Nanotopography / G. Mendonca [et al.] // Biomaterials. - 2008. - Vol. 29, № 28. - P. 3822-3835. - DOI: https://doi.org/10.1016/ j.biomaterials.2008.05.012.

6. Alpaslan, E. Anodized $20 \mathrm{~nm}$ Diameter Nanotubular Titanium for Improved Bladder Stent Applications / E. Alpaslan, B. Ercan, T. J. Webster // Int. J. Nanomedicine. - 2011. - Vol. 6. - P. 219-225. DOI: https://doi.org/10.2147/IJN.S15816

7. Chang, P. C. Evaluation of Functional Dynamics During Osseointegration and Regeneration Associated with Oral Implants: A Review / P. C. Chang, N. P. Lang, W. V. Giannobile // Clin. Oral Implants Res. 2010. - Vol. 21, № 1. - P. 1-12. - DOI: https://doi.org/ 10.1111/j.1600-0501.2009.01826.x.

8. Classification of Osseointegrated Implant Surfaces: Materials, Chemistry and Topography / D.M.D. Ehrenfest [et al.] // Trends Biotechnol. 2010. - Vol. 28, № 4. - P. 198-206. - DOI: https://doi.org/ 10.1016/j.tibtech.2009.12.003.

9. Electrophoretic Deposition of Carbon Nanotubes and Bioactive Glass Particles for Bioactive Composite Coatings / M.C. Schausten [et al.] // Ceramics Int. - 2010. - Vol. 36, № 1. - P. 307-312. DOI: https://doi.org/10.1016/j.ceramint.2009.09.008.
10. Evaluation of Survival and Success Rates of Dental Implants Reported in Longitudinal Studies with a Follow-Up Period of at Least 10 Years: A Systematic Review / V. Moraschini [et al.] // Int. J. Oral Maxillofac. Surg. - 2015. - Vol. 44, № 3. - P. 377-388. - DOI: https://doi.org/10.1016/j.ijom.2014.10.023.

11. Implant Biomaterials: A Comprehensive Review / M. Saini [et al.] // World J. Clin. Cases. 2015. - Vol. 3, № 1. - P. 52-57. - DOI: https://doi.org/ 10.12998/wjcc.v3.i1.52.

12. King, W. J. Growth Factor Delivery: How Surface Interactions Modulate Release in Vitro and in Vivo / W. J. King, P. H. Krebsbach // Adv. Drug Deliv. Rev. - 2012. - Vol. 64, № 12. - P. 1239-1256. - DOI: https://doi.org/10.1016/j.addr.2012.03.004.

13. Lateral Spacing of Integrin Ligands Influences Cell Spreading and Focal Adhesion Assembly / E. A. Cavalcanti-Adam [et al.] // Eur. J. Cell Biol. - 2006. - Vol. 85, № 3-4. - P. 219-224. - DOI: https://doi.org/10.1016/j.ejcb.2005.09.011.

14. Scanning Electron Microscope (SEM) Evaluation of the Interface Between a Nanostructured Calcium-Incorporated Dental Implant Surface and the Human Bone / F. Mangano [et al.] // Materials (Basel). 2017. - Vol. 10, № 12. - P. 1438. - DOI: https://doi.org/ 10.3390/ma10121438.

15. Stanford, C. M. Surface Modification of Biomedical and Dental Implants and the Processes of Inflammation, Wound Healing and Bone Formation / C. M. Stanford // Int. J. Mol. Sci. - 2010. - Vol. 11, № 1. - P. 354-369. - DOI: https://doi.org/10.3390/ ijms11010354.

16. The Anatase Phase of Nanotopography Titania Plays an Important Role on Osteoblast Cell Morphology and Proliferation/J. He [et al.]// J. Mater. Sci. Mater. Med. - 2008. - Vol. 19, № 11. - P. 3465-3472. DOI: https://doi.org/10.1007/s10856-008-3505-3.

17. Tonetti, M. Working Group 2 of the VIII European Workshop on Periodontology.Clinical Research in Implant Dentistry: Study Design, Reporting and Outcome Measurements. Consensus Report of Working Group 2 of the VIII European Workshop on Periodontology / M. Tonetti, R. Palmer // J. Clin. Periodontol. - 2012. - Vol. 39, № 12. - P. 73-80. - DOI: https://doi.org/10.1111/ j.1600-051X.2011.01843.x.

\section{REFERENCES}

1. Kostenko Ye.Ya., Kenyuk A.T., Dychek Z.Z. Analiz metodov otsenki poter' urovnya kostnoy tkani $\mathrm{v}$ periimplantatnom uchastke na osnove rezul'tatov rentgenologicheskikh issledovaniy [Analysis of Methods for Assessing the Loss of the Level of Bone Tissue in the Peri-Implant Site Based on the Results 
of X-Ray Studies]. Sovremennaya stomatologiya [Modern Dentistry]. 2016, vol. 2, no. 81, pp. 76-79.

2. Labis V.V., Bazikyan E.A., Kozlov I.G., et al. Nanorazmernyye chastitsy - uchastniki osteointegratsii [Nanosized Particles are Participants in Osseointegration]. Byulleten' Orenburgskogo nauchnogo tsentra UrO RAN [Bulletin of the Orenburg Scientific Center of the Ural Branch of the Russian Academy of Sciences]. 2016, no. 1, pp. 1-18.

3. Novochadov V.V., Gayfullin N.M., Zalevskiy D.A., et al. Osteointegratsiya implantatov s bioaktivnoy poverkhnost'yu, modifitsirovannoy napyleniyem khitozana $\mathrm{v}$ eksperimente u krys [Osseointegration of implants with a bioactive surface modified by sputtering of chitosan in an experiment in rats]. Rossiyskiy mediko-biologicheskiy vestnik im. akademika I.P. Pavlova [Russian Medical and Biological Bulletin Named After Academician I.P. Pavlova]. 2013, vol. 21, no. 2, pp. 30-35.

4. Albertini M., Fernandez-Yague M., Lázaro P., et al. Advances in Surfaces and Osseointegration in Implantology. Biomimetic Surfaces. Med. Oral Patol. Oral Cir. Bucal, 2015, vol. 20, no. 3, pp. e316-e325. DOI: https://doi.org/10.4317/medoral.20353.

5. Alpaslan E., Ercan B., Webster T.J. Anodized $20 \mathrm{~nm}$ Diameter Nanotubular Titanium for Improved Bladder Stent Applications. Int. J. Nanomedicine, 2011, vol. 6, pp. 219-225.DOI: https://doi.org/10.2147/IJN.S15816.

6. Chang P.C., Lang N.P., Giannobile W.V. Evaluation of Functional Dynamics During Osseointegration and Regeneration Associated with Oral Implants: A Review. Clin. Oral Implants Res., 2010, vol. 21, no. 1, pp. 1-12. DOI: https://doi.org/10.1111/ j.1600-0501.2009.01826.x.

7. Dohan Ehrenfest D.M., Coelho P.G., Kang B.S., et al. Classification of Osseointegrated Implant Surfaces: Materials, Chemistry and Topography. Trends Biotechnol, 2010, vol. 28, no. 4, pp. 198-206. DOI: https://doi.org/10.1016/ j.tibtech.2009.12.003.

8. Schausten M.C., Meng D.C., Telle R., et al. Electrophoretic Deposition of Carbon Nanotubes and Bioactive Glass Particles for Bioactive Composite Coatings. Ceramics Int., 2010, vol. 36, no. 1, pp. 307-312. DOI: https://doi.org/10.1016/ j.ceramint.2009.09.008.

9. Moraschini V., Poubel L.A., Ferreira V.F., et al. Evaluation of Survival and Success Rates of Dental Implants Reported in Longitudinal Studies with a
Follow-Up Period of at Least 10 Years: A Systematic Review. Int. J. Oral Maxillofac. Surg., 2015, vol. 44, no. 3, pp. 377-388. DOI: https://doi.org/10.1016/ j.ijom.2014.10.023.

10. Saini M., Singh Y., Arora P., et al. Implant Biomaterials: A Comprehensive Review. World J. Clin. Cases., 2015, vol. 3, no. 1, pp. 52-57. DOI: https:// doi.org/10.12998/wjcc.v3.i1.52.

11. King W.J., Krebsbach P.H. Growth Factor Delivery: How Surface Interactions Modulate Release in Vitro and in Vivo. Adv. Drug Deliv. Rev., 2012, vol. 64, no. 12, pp. 1239-1256. DOI: https://doi.org/10.1016/ j.addr.2012.03.004.

12. Cavalcanti-Adam E.A., Micoulet A., Blummel J., et al. Lateral Spacing of Integrin Ligands Influences Cell Spreading and Focal Adhesion Assembly. Eur. J. Cell Biol., 2006, vol. 85, no. 3-4, pp. 219-224. DOI: https://doi.org/10.1016/j.ejcb. 2005.09.011.

13. Mendonca G., Mendonca D.B., Aragao F.J., et al. Advancing Dental Implant Surface Technology from Micron - to Nanotopography. Biomaterials, 2008, vol. 29, no. 28, pp. 3822-3835. DOI: https://doi.org/ 10.1016/j.biomaterials.2008.05.012.

14. Mangano F., Raspanti M., Maghaireh H., et al. Scanning Electron Microscope (SEM) Evaluation of the Interface Between a Nanostructured CalciumIncorporated Dental Implant Surface and the Human Bone. Materials (Basel), 2017, vol. 10, no. 12, p. 1438. DOI: https://doi.org/10.3390/ma10121438.

15. Stanford C.M. Surface Modification of Biomedical and Dental Implants and the Processes of Inflammation, Wound Healing and Bone Formation. Int. J. Mol. Sci., 2010, vol. 11, no. 1, pp. 354-369. DOI: https://doi.org/10.3390/ijms11010354.

16. He J., Zhou W., Zhou X., et al. The Anatase Phase of Nanotopography Titania Plays an Important Role on Osteoblast Cell Morphology and Proliferation. J. Mater. Sci. Mater. Med., 2008, vol. 19, no. 11, pp. 3465-3472. DOI: https://doi.org/10.1007/s10856008-3505-3.

17. Tonetti M., Palmer R. Working Group 2 of the VIII European Workshop on Periodontology Clinical Research in Implant Dentistry: Study Design, Reporting and Outcome Measurements. Consensus report of Working Group 2 of the VIII European Workshop on Periodontology. J. Clin. Periodontol, 2012, vol. 39, no. 12, pp. 73-80. DOI: https://doi.org/ 10.1111/j.1600-051X.2011.01843.x. 


\section{Information About the Authors}

Tatyana S. Lyzo, Student, Department of Bioengineering and Bioinformatics, Volgograd State University, Prosp. Universitetsky, 100, 400062 Volgograd, Russian Federation, fkbcf-fkbcf@inbox.ru

Anastasia A. Korchagina, Student, Department of Bioengineering and Bioinformatics, Volgograd State University, Prosp. Universitetsky, 100, 400062 Volgograd, Russian Federation, nastya.korchagina09@gmail.com

Anna S. Krylova, Postgraduate Student, Department of Bioengineering and Bioinformatics, Volgograd State University, Prosp. Universitetsky, 100, 400062 Volgograd, Russian Federation, krylova.volsu@mail.ru

\section{Информация об авторах}

Татьяна Сергеевна Лызо, студент кафедры биоинженерии и биоинформатики, Волгоградский государственный университет, просп. Университетский, 100, 400062 г. Волгоград, Российская Федерация, fkbcf-fkbcf@inbox.ru

Анастасия Александровна Корчагина, студент кафедры биоинженерии и биоинформатики, Волгоградский государственный университет, просп. Университетский, 100, 400062 г. Волгоград, Российская Федерация, nastya.korchagina09@gmail.com

Анна Сергеевна Крылова, аспирант кафедры биоинженерии и биоинформатики, Волгоградский государственный университет, просп. Университетский, 100, 400062 г. Волгоград, Российская Федерация, krylova.volsu@mail.ru 